app. Theoretically, the ICO is able to fine companies up to $£ 500,000$ for breaches of the relevant legislation, although this power has yet to be used against mobile app developers. However, the threat of action will surely motivate app developers and Appstores alike in this area.

Daisy Jones, Associate, Osborne Clarke, London

\title{
German privacy regulator imposes $€ 1,300,000$ fine on insurance giant Debeka
}

\author{
Flemming Moos
}

Journal of Direct, Data and Digital Marketing Practice (2015) 16, 226-227. doi:10.1057/dddmp.2015.10

Who: Data Protection Authority of Rhineland-Palatinate

Where: Germany

When: 29 December 2014

What happened

Why this matters
The regional German Data Protection Authority (DPA) of RhinelandPalatinate imposed a record fine of $€ 1,300,000$ on insurance giant Debeka after its sales staff allegedly sought address data of business customers' employees in order to offer them Debeka's consumer products. The case did not only attract the attention of the DPA. The Public Prosecutor initiated investigations against five employees because of an alleged incitement of civil servants to violate secrecy obligations and data protection laws by disclosing details on other officials in order for Debeka to market their services to them. On top of this, Germany's insurance regulator, the Federal Financial Supervisory Authority (BaFin), conducted an investigation and required various improvements of the company's data protection organization.

At first glance, the case is all about proper marketing use of data. It reminds businesses that data must generally be collected directly from the affected individual; otherwise the individual must have clearly consented to the forwarding of his details to a third party. In particular, the call by BaFin for genuine improvements to Debeka's business organization through the strengthening of the internal data protection framework shows, however, that it has a much more fundamental impact.

Further, BaFin required the company to:

- fully document the origin of all data on potential new customers;

- install a proper data protection organization, for example, by entrusting specific employees with the oversight of the proper collection and use of personal data; 


\section{Stress test your data protection}

What happened

This year's priorities

Targeted scams
- foster the company's compliance organization, for example, by establishing a whistleblowing hotline;

- train employees in data protection matters.

Never before has a German supervisory authority stressed so clearly the need for proper data protection management. All companies that process customer or employee data on a large scale should put their organization to the test - the best way to avoid fines and publicity for data protection violations.

Dr Flemming Moos, partner, Osborne Clarke, Hamburg

\section{Consumer protection partnership reports on enforcement priorities for 2015}

Stephen Groom

Journal of Direct, Data and Digital Marketing Practice (2015) 16, 227-230. doi:10.1057/dddmp.2015.12

Who: Consumer Protection Partnership, including Competition and Markets Authority, Financial Conduct Authority, National Trading Standards and Citizens' Advice

When: January 2015

Where: Westminster, UK

Law stated as at: 4 February 2015

The Consumer Protection Partnership (CPP) was formed in 2012. Its members comprise all the key bodies tasked with enforcing and giving guidance on UK consumer protection laws, including laws impacting advertising and marketing. The membership roster includes the Office of Fair Trading's (OFT's) successor body, the Competition and Markets Authority (CMA), the Financial Conduct Authority, National Trading Standards and Citizens' Advice. Formed at the time of the impending scrapping of the OFT, the CPP was intended to help make better, 'joinedup', use of the more limited resources being made available for enforcement of consumer protection laws.

The CPP's 'Priorities Report 2015' identifies its strategic priorities for scrutiny and action in 2015. It also mentions its previous priorities for 2013-2014.

Mass marketing scams: Well-known scams included lottery mailings, PPI mis-selling claims services, false competition wins, offers of phoney jobs, and Green Deal and cash voucher scams. Often targeted were 